Reviu Akuntansi dan Bisnis Indonesia, Vol. 5 No. 2, Hlm 208-216, Desember 2021

Website: http://journal.umy.ac.id/index.php/rab

\title{
Peran Tata kelola perusahaan pada Pengaruh Utang dan Profitabilitas terhadap Penghindaran Pajak
}

\author{
Dessy Kartikasari; Etik Kresnawati \\ Program Studi Akuntansi Universitas Muhammadiyah Yogyakarta
}

I N F O A R T I K E L

\section{Kata Kunci:}

Perception; Ethics; Social

Responsibility;

Machiavellianism; Ethical

Reasoning; Ethical Decision

Making

Jenis Artikel:

Penelitian Empiris

Korespondensi:

dessytikahehe@gmail.com

\section{Proses Artikel:}

Diterima 5 November 2021

Review 12 Desember 2021

Revisi 28 Desember 021

Revisi 30 Desember 2021

Diterbitkan Desember 2021

Sitasi:

Kartikasari, D., \& Kresnawati,

E. (2021). Peran Tata kelola

perusahaan pada Pengaruh

Utang dan Profitabilitas

terhadap Penghindaran Pajak.

Reviu Akuntansi dan Bisnis

Indonesia, 5(2), 208-216.

Link Artikel:

10.18196/rabin.v5i2.13708

\section{A B S T R A K}

Latar Belakang:

Masih banyak kasus penghindaran pajak (tax avoidance) yang dilakukan oleh perusahaan di Indonesia dengan memanfaatkan kelemahan peraturan perpajakan. Walaupun praktik penghindaran pajak bukan tindakan yang illegal, tetapi dapat mengurangi pendapatan negara.

\section{Tujuan:}

Penelitian ini bertujuan untuk menguji pengaruh utang dan profitabilitas terhadap penghindaran pajak yang dimoderasi dengan tata kelola perusahaan.

\section{Metode Penelitian:}

Penelitian ini adalah pengujian data panel dari 44 perusahaan (132 sampel observasi) yang terdaftar di Bursa Efek Indonesia pada tahun 2018-2020. Sampel ditentukan dengan metode penyampelan bersasaran (purposive sampling). Data dianalisis dengan metode regresi data panel.

\section{Hasil Penelitian:}

Hasil pengujian menunjukkan bahwa utang tidak berpengaruh terhadap penghindaran pajak, sedangkan profitabilitas berpengaruh negative terhadap penghindaran pajak. Tata kelola perusahaan yang diprosi dengan rasio komisaris independen juga tidak memoderasi pengaruh kedua variabel independent terhadap variabel dependen.

\section{Keterbatasan Penelitian:}

Sampel awal yang tidak digunakan dalam penelitian ini relative besar. Hal ini boleh jadi karena pada tahun 2019 dan 2020 kondisi perekonomian dunia sedang terpuruk sehingga banyak sampel tidak memenuhi kriteria yang ditetapkan. Selain itu, rasio dewan komisaris independen sebagai proksi tata kelola perusahaan tidak cukup bervariasi karena perusahaan boleh jadi hanya sekedar memenuhi syarat rasio yang ditetapkan dalam peraturan perundang-undangan.

\section{Keaslian/Novetly Penelitian:}

Penelitian ini adalah replikasi dari penelitian sebelumnya yang diuji kembali pada perusahaan manufaktur dengan menggunakan data panel.

(C) 2021 RAB. Published by Universitas Muhammadiyah Yogyakarta

\section{PENDAHULUAN}

Pajak merupakan sumber penerimaan utama yang digunakan untuk pembangunan negara. Terdapat perbedaan kepentingan antara pihak Wajib Pajak dengan pihak pemerintah dalam 
pelaksanaan perpajakannya. Di pihak pemerintah, pajak digunakan sebagai tunjangan utama dalam menyelenggarakan pemerintahan, sedangkan di pihak Wajib Pajak merupakan beban yang harus dibayarkan (Reinaldo, 2017). Perbedaan kepentingan antara pihak pemerintah dan pihak Wajib Pajak dapat memengaruhi beberapa jumlah penerimaan pajak yang masuk. Berikut ini merupakan tabel pencapaian penerimaan negara (dari sektor pajak) di Indonesia periode 2016 - 2020:

Tabel 1 Data Anggaran dalam Penerimaan Pajak Negara Indonesia

\begin{tabular}{cccc}
\hline \multicolumn{4}{c}{ Target dan Realisasi Anggaran dalam Penerimaan Pajak Negara Indonesia } \\
Periode & Target (triliun) & Realisasi (triliun) & Pencapaian \\
\hline 2016 & Rp1,539 & Rp1,285 & $84 \%$ \\
2017 & Rp1,473 & Rp1,344 & $91 \%$ \\
2018 & Rp1,618 & Rp1,519 & $94 \%$ \\
2019 & Rp1,786 & Rp1,546 & $87 \%$ \\
2020 & Rp1,405 & Rp1,285 & $92 \%$ \\
\hline
\end{tabular}

Sumber: Laporan Keuangan Kementrian Keuangan 2016 - 2020

Jika dilihat dari perbandingan antara target dengan realisasi dalam jumlah penerimaan pajak di negara Indonesia periode 2016 - 2020, dapat diketahui bahwa jumlah realisasi pajak tidak sesuai dengan target yang telah ditetapkan. Perusahaan merupakan salah satu Wajib Pajak yang dapat memiliki dorongan untuk melakukan praktik penghindaran pajaknya. Penghindaran pajak merupakan suatu upaya untuk mengurangi jumlah pajak dengan cara mencari kelemahan dalam peraturan (Hutagaol, 2007). Praktik penghindaran pajak dilakukan dengan cara memanfaatkan kelemahan (loopholes) yang terdapat dalam peraturan perpajakan, sehingga dapat dikatakan legal karena tidak melanggar peraturan yang berlaku.

Penelitian sebelumnya menunjukkan bahwa jumlah utang, tingkat penjualan, dan tingkat laba adalah sejumlah faktor yang memengaruhi perusahaan dalam melakukan penghindaran pajaknya (Arinda \& Dwimulyani, 2018). Utang dimanfaatkan oleh perusahaan dalam membiayai aktivitas operasinya. Walaupun penggunaan utang akan menyebabkan timbulnya beban tetap (fixed rate of return) berupa bunga tetapi di sisi lain dapat mengurangi penghasilan pajak (Praditasari \& Setiawan, 2017). Penelitian yang dilakukan oleh Astari dkk. (2019) menunjukkan bahwa beban bunga yang semakin tinggi akan mengurangi jumlah beban pajak perusahaan, sehingga penggunaan utang berpengaruh positif terhadap penghindaran pajak. Adapun penelitian yang dilakukan oleh Mahdiana dan Amin (2020) yang mengungkapkan bahwa utang memiliki pengaruh positif terhadap penghindaran pajak. Namun demikian, penelitian Aprianto dan Dwimulyani (2019) menunjukkan sebaliknya yaitu utang berpengaruh negatif terhadap penghindaran pajak.

Desai dan Dharmapala (2006) mengungkapkan bahwa motif perusahaan dalam melakukan praktik penghindaran pajaknya yakni sebagai upaya yang dilakukan oleh seorang manajer untuk memperbesar keuntungan yang ingin dicapai oleh para pemegang saham. Kemampuan perusahaan dalam memperoleh laba atau keuntungannya ditunjukkan melalui tingkat profitabilitas perusahaan. Perusahaan dengan laba yang tinggi akan dapat memanfaatkan celah dalam pengelolaan beban pajaknya (Dewinta \& Setiawan, 2016). Hasil penelitian yang dilakukan oleh Dewi dan Noviari (2017) menunjukkan bahwa profitabilitas berpengaruh positif terhadap penghindaran pajak karena semakin tinggi tingkat profitabilitas mempunyai konsekuensi semakin tinggi pula jumlah pajak yang harus dibayar, sehingga perusahaan yang memiliki tingkat profitabilitas yang tinggi akan cenderung melakukan praktik penghindaran pajak.

Tidak ada unsur pidana yang akan dikenakan pada praktik penghindaran pajak, karena perusahaan tetap bertransaksi dengan baik dan tidak melanggar hukum. Namun demikian, upaya perusahaan untuk menghindari pajak dapat berdampak pada menurunnya respon pemegang saham (Fahmi \& Prayoga, 2018; Mahetri dan Muliati 2020). Oleh karena itu perlu adanya tata kelola perusahaan yang baik untuk menjamin berlangsungnya praktik usaha yang baik. Tata kelola perusahaan menjelaskan hubungan antara berbagai partisipan dalam perusahaan yang menentukan arah kinerja perusahaan (Haruman, 2008). Penelitian terdahulu yang dilakukan oleh Arinda dan Dwimulyani (2018) mengungkapkan bahwa tata kelola perusahaan yang baik dengan menggunakan 
pengukuran ACGS (Asean Corporate Governance Scorecard) dapat memoderasi pengaruh profitabilitas dan utang terhadap penghindaran pajak.

Untuk mengkonfirmasi hasil penelitian sebelumnya yang tidak konsisten, penelitian ini bertujuan untuk menguji kembali pengaruh utang dan profitabilitas terhadap penghindaran pajak yang dimoderasi dengan tata kelola perusahaan. Pengujian dilakukan pada perusahaan manufaktur yang terdaftar di Bursa Efek Indonesia periode 2018-2020.

\section{TINJAUAN LITERATUR DAN PERUMUSAN HIPOTESIS}

Teori keagenan Jensen dan Meckling (1976) menjelaskan hubungan kontraktual antara pihak yang memberikan kekuasaan (principals/pemegang saham) dengan pihak yang menerima kekuasaan (agents/manajemen). Teori ini mengasumsikan bahwa manajemen sebagai pihak dalam perusahaan (insider) mempunyai kecenderungan untuk berperilaku oportunistik untuk memaksimalkan kepentingan pribadinya. Hal ini dapat terjadi karena adanya asimetri informasi antara kedua belah pihak. Terkait dengan penghindaran pajak, manajemen dapat mengelola pelaporan pajak perusahaan yang akan berdampak pada meningkatnya laba perusahaan tanpa sepengetahuan pemegang saham. Dari aktivitas ini, manajemen akan diuntungkan dengan reward yang lebih baik bila kontrak kompensasinya didasarkan pada laba perusahaan. Walaupun laba perusahaan meningkat, upaya manajemen untuk menghindari pajak dapat berdampak pada menurunnya respon pemegang saham (Fahmi \& Prayoga, 2018; Mahetri \& Muliati 2020).

\section{Pengaruh utang terhadap penghindaran pajak}

Perusahaan dapat meminimalisir pembayaran pajaknya melalui penggunaan utang sebagai pendanaan aktivitas operasionalnya. Hal tersebut dikarenakan penggunaan utang akan menimbulkan beban tetap yang biasa disebut dengan bunga. Bunga dipergunakan sebagai pengurang laba sebelum pajak perusahaan. Laba sebelum pajak yang semakin rendah akan berdampak pada semakin rendahnya beban pajak yang harus dibayar oleh perusahaan. Tingginya tingkat utang menunjukkan bahwa perusahaan memiliki kecenderungan dalam melakukan penghindaran pajak dengan memanfaatkan beban bunga yang timbul akibat penggunaan utang untuk mengurangi beban pajak perusahaan (Sinaga \& Suardikha, 2019). Penjelasan tersebut juga didukung dengan hasil penelitian yang dilakukan oleh Mahdiana dan Amin (2020) dan Sunarsih dkk. (2019) yang menunjukkan bahwa utang berpengaruh positif terhadap penghindaran pajak. Berdasarkan penjelasan tersebut, maka dapat dihipotesiskan sebagai berikut:

\section{$\boldsymbol{H}_{\boldsymbol{I}}$ : Utang berpengaruh positif terhadap penghindaran pajak.}

\section{Pengaruh profitabilitas terhadap penghindaran pajak}

Salah satu tujuan utama manajemen adalah melakukan pengelolaan perusahaan yang akan menghasilan laba maksimal. Semakin tinggi tingkat laba yang diperoleh, maka semakin tinggi jumlah pajak penghasilan secara proporsional, sehingga perusahaan yang memiliki tingkat profitabilitas yang tinggi akan cenderung melakukan praktik penghindaran pajak (Dewi \& Noviari, 2017). Perusahaan dengan jumlah keuntungan yang besar akan lebih leluasa untuk memanfaatkan celah dalam mengelola beban perpajakannya, sehingga perusahaan akan cenderung melakukan praktik penghindaran pajak guna meminimalisir beban pajaknya (Pitaloka \& Merkusiwati, 2019). Hasil penelitian yang dilakukan oleh Praditasari dan Setiawan (2016) juga menunjukkan bahwa profitabilitas berpengaruh positif terhadap penghindaran pajak. Berdasarkan penjelasan tersebut, maka dapat dihipotesiskan sebagai berikut:

\section{$\boldsymbol{H}_{2}$ : Profitabilitas berpengaruh positif terhadap penghindaran pajak.}




\section{Pengaruh Tata kelola perusahaan dalam Memoderasi Pengaruh Utang terhadap Penghindaran Pajak}

Perusahaan yang menggunakan utangnya sebagai pendanaan akan memberikan sinyal positif bagi para investor. Hal tersebut dikarenakan perusahaan telah yakin dengan masa depan prospek kerjanya. Namun jika perusahaan memiliki nilai utang yang tinggi, maka semakin rendah kesadaran perusahaan dalam membayarkan beban pajaknya sehingga perusahaan akan cenderung melakukan praktik penghindaran pajak. Seperti yang dijelaskan dalam teori keagenan bahwa manajemen sangat berpeluang untuk mengambil kebijakan yang tidak selaras denngan kepentingan pemegang saham, maka tata kelola perusahaan menjadi sangat penting. Bentuk tata kelola ini dapat berupa adanya komisaris independent yang akan memaksimalkan pengawasan terhadap tindakan manajemen dalam mengelola perusahaan, termasuk tindakan yang berkaitan dengan pembayaran pajak (Muliawati \& Karyada, 2020). Tata kelola perusahaan yang baik akan menurunkan diskresi manajemen dalam melakukan penghindaran pajak. Berdasarkan uraian tersebut, maka dapat diturunkan hipotesis sebagai berikut:

\section{$\boldsymbol{H}_{3}$ : Tata kelola perusahaan memperlemah pengaruh posistif utang terhadap penghindaran pajak.}

\section{Pengaruh Tata kelola perusahaan dalam Memoderasi Pengaruh Profitabilitas terhadap Penghindaran Pajak}

Teori keagenan memprediksi bahwa manajemen akan memaksimalkan keuntungan pribadinya dengan memanfaatkan kedudukannya sebagai pembuat kebijakan dan pihak dalam perusahaan. Terkait laba, manajemen akan berusaha mengelola beban pajak perusahaan agar tidak mengurangi kompensasi sebagai dampak dari berkurangnya laba perusahaan oleh beban pajak tersebut (Darmawan \& Sukartha, 2014). Besar kecilnya laba yang akan diperoleh, dapat memengaruhi jumlah pembayaran pajak yang akan dikeluarkan. Semakin besar keuntungan yang diperoleh, maka semakin besar pajak yang akan dibayar. Sebaliknya, jika semakin kecil keuntungan yang diperoleh, maka semakin kecil pajak yang dibayar.

Menurut Boediono (2005), untuk memitigasi tindakan oportunistik manajemen, peran komisaris independen dalam menjalankan fungsi pengawasan akan dapat memengaruhi pihak manajemen dalam penyusunan laporan keuangan sehingga dapat diperoleh laporan laba yang berkualitas. Dengan adanya komisaris independen, maka pengawasan terhadap laporan keuangan akan lebih diperketat dan objektif, sehingga dapat meminimalisir kecurangan yang dilakukan oleh manajer dalam manipulasi laba perusahaan (Diantari \& Ulupui, 2016). Berdasarkan penjelasan tersebut, maka dapat diambil hipotesis sebagai berikut:

\section{$\boldsymbol{H}_{4}$ : Tata kelola perusahaan memperlemah pengaruh posistif profitabilitas terhadap penghindaran pajak.}

\section{METODE PENELITIAN}

\section{Sampel Penelitian dan Teknik Penyampelan}

Penelitian ini menggunakan data sekunder yang diambil melalui laporan keuangan perusahaan manufaktur yang terdaftar di BEI periode 2018-2020. Laporan keuangan diperoleh dari situs Bursa Efek Indonesia (www.idx.co.id). Sampel yang digunakan dalam penelitian ini adalah perusahaan manufaktur yang terdaftar di BEI periode 2018 - 2020 dengan total populasi sebanyak 162 perusahaan. Jumlah perusahaan yang dijadikan sampel pada penelitian ini sebanyak 44 perusahaan dengan total pengamatan sebanyak 132 sampel. Sampel dalam penelitian ini ditentukan dengan metode purposive sampling. Adapun kriteria yang digunakan oleh peneliti, yakni: (1) perusahaan manufaktur yang terdaftar di BEI periode 2018 - 2020, (2) perusahaan manufaktur yang mempublikasikan laporan keuangan selama tahun penelitian 2018 - 2020, (3) perusahaan manufaktur yang tidak mengalami kerugian selama periode 2018 - 2020, (4) perusahaan 
manufaktur yang menggunakan mata uang rupiah dalam penyajian laporan keuangan, (5) perusahaan yang memiliki data lengkap terkait dengan penelitian ini.

\section{Variabel Penelitian}

Variabel independent dalam penelitian ini adalah penghindaran pajak yang diukur dengan CETR (Cash Effective Rate) yaitu rasio jumlah kas yang dibayar terhadap laba sebelum pajak yang dihasilkan oleh perusahaan. Hasil perhitungan dari rumus tersebut berlawanan dengan makna variabel yang diukur karena semakin tinggi tingkat persentase CETR (mendekati tarif pajak penghasilan sebesar 25\%), semakin rendah kecenderungan perusahaan dalam melakukan penghindaran pajak.

Variabel dependen dalam penelitian ini adalah utang (leverage) dan profitabilitas. Tingkat utang sebagai penilai seberapa besar aset perusahaan yang diperoleh dengan menggunakan utang yang diukur dengan DAR (Debt to Asset Ratio) dengan rumus total kewajiban dibagi dengan total asset. Profitabilitas adalah kemampuan perusahaan perseorangan atau badan untuk menghasilkan laba dengan memperhatikan penggunaan modal (Wati dan Astuti, 2020). Dalam penelitian ini, profitabilitas diukur dengan ROE (Return on Equity) dengan rumus laba bersih dibagi total ekuitas.

Variabel pemoderasi dalam penelitian ini adalah Tata kelola perusahaan yang diproksi dengan keberadaan dewan komisaris independent di perusahaan. Variabel ini diukur dengan rumus jumlah dewan komisaris independent dibagi dengan total komisaris di perusahaan.

\section{Teknik Pengujian}

Data penelitian yang akan diuji adalah data panel. Oleh karena itu peneliti menggunakan mekanisme pengujian data panel dengan terlebih dahulu mengestimasi model regresi yang sesuai, yaitu apakah menggunakan common effect model (CEM), fixed effect model (FEM) atau random effect model (REM). Setelah itu baru dilakukan pengujian hipotesis sesuai dengan model yg estimasi. Pengujian dilakukan dengan software EViews 10. Berikut ini adalah rumus regresi untuk menguji hipotesis penelitian:

Berikut adalah persamaan regresinya:

$\mathrm{TA}=\boldsymbol{\alpha}+\beta_{1} \mathrm{Lev}+\boldsymbol{\beta}_{2}$ Prof $+\beta_{3} \mathrm{CG}+\boldsymbol{\beta}_{4} \mathrm{Lev}^{*} \mathrm{CG}+\boldsymbol{\beta}_{5}$ Prof $^{*} \mathrm{CG}+\mathrm{e}$

Keterangan: TA $=$ penghindaran pajak (tax avoidance); $\alpha=$ konstanta; $\beta=$ koefisien regresi; Lev $=$ utang (leverage); Prof = profitabilitas; $\mathrm{CG}=$ Tata kelola perusahaan $($ Corporate Governance $) ; \mathrm{e}=$ galat.

\section{HASIL DAN PEMBAHASAN}

\section{Statistik Deskriptif}

Tabel 1 Statistik Deskriptif

\begin{tabular}{lcccc}
\hline & DAR & ROE & CG & CETR \\
\hline Mean & 0,358098 & 0,113939 & 0,352985 & 0,237765 \\
Median & 0,339000 & 0,101500 & 0,333000 & 0,230500 \\
Maximum & 0,845000 & 0,295000 & 0,500000 & 0,532000 \\
Minimum & 0,092000 & 0,006000 & 0,000000 & 0,000000 \\
Std. Dev. & 0,175431 & 0,066626 & 0,096727 & 0,104535 \\
\hline Skewness & 0,494155 & 0,648380 & $-1,260945$ & 0,286094 \\
Jarque-Bera & 5,937643 & 9,467661 & 161,9246 & 2,105794 \\
Probability & 0,051364 & 0,008793 & 0,000000 & 0,348926 \\
\hline Sum & 47,26900 & 15,04000 & 46,59400 & 31,38500 \\
Sum Sq. Dev. & 4,031670 & 0,581508 & 1,225660 & 1,431502 \\
\hline
\end{tabular}




\section{Uji Kriteria Pemilihan Model Terbaik}

\section{Uji Chow}

Tabel 2 Uji Chow

\begin{tabular}{lccc}
\hline Effect Test & Statistic & d.f. & Prob. \\
\hline Cross-Section F & 1,688930 & $(43,85)$ & 0,0203 \\
Cross-section Chi-square & 81,518077 & 43 & 0,0004 \\
\hline
\end{tabular}

Berdasarkan Tabel 3, nilai probability Cross-section F sebesar 0,0203 $<0,05$ dan nilai probability Cross-section Chi-square sebesar 0,0004<0,05. Dari hasil tersebut, dapat disimpulkan bahwa FEM merupakan model yang lebih baik daripada CEM.

\section{Uji Hausman}

Tabel 3 Uji Hausman

\begin{tabular}{lccc}
\hline Test Summary & Chi-Sq. Statistic & Chi-Sq. d.f. & Prob. \\
\hline Cross-section random & 9,302622 & 3 & 0,0255 \\
\hline
\end{tabular}

Berdasarkan hasil uji hausman pada Tabel 4, diperoleh nilai probability Cross-section random sebesar 0,0255 < 0,05. Dari hasil tersebut, dapat disimpulkan bahwa FEM merupakan model yang terbaik daripada REM. Berdasarkan hasil uji kriteria pemilihan model terbaik diatas, dapat disimpulkan bahwa data penelitian ini menggunakan FEM dalam melakukan regresi data panel selanjutnya. FEM merupakan pilihan model terbaik pada data penelitian ini, maka dari itu tidak perlu dilakukan Uji LM (Lagrange Multiplier).

\section{Uji Hipotesis}

Model FEM menggunkaan pendekatan Ordinary Least Squared (OLS). Oleh karena itu penulis melakukan pengujian asumsi klasik meliputi uji normalitas data, multikolinearitas dan heteroskedastisitas sebelum melakukan pengujian hipotesis. Hasil uji Normalitas menunjukkan bahwa nilai residual terdistribusi normal yang ditunjukkan dengan nilai probabilitas sebesar 0,257624. Data penelitian juga tidak ada multikolinearitas antara variabel independent yang ditunjukkan dengan nilai korelasi antar variabel independen $<0,90$. Data penelitian juga terbebas dari heteroskedastisitas yang ditunjukkan dengan nilai Prob. Chi-Square (Obs ${ }^{*} \mathrm{R}$-squared) sebesar 0,1224 .

Hipotesis penelitian diuji dengan menggunakan model FEM dengan hasil sebagai berikut:

Tabel 5 Hasil Uji Regresi

\begin{tabular}{lcccc}
\hline Variabel & Coefficient & Std. Error & t-Statistic & Prob. \\
\hline C & 0,277006 & 0,124132 & 2,231542 & 0,0283 \\
DAR & 0,406857 & 0,267230 & 1,522494 & 0,1317 \\
ROE & $-0,804178$ & 0,372378 & $-2,159577$ & 0,0337 \\
CG & $-0,175529$ & 0,317207 & $-0,553359$ & 0,5815 \\
DAR $^{*}$ CG & $-0,597459$ & 0,646041 & $-0,924800$ & 0,3578 \\
ROE $^{*}$ CG & 1,011622 & 0,870582 & 1,162006 & 0,2486 \\
\hline R-squared & & 0,709075 & & \\
Adjusted R-squared & & 0,540830 & & \\
S.E. of regression & & 0,090462 & & \\
F-statistic & 4,214524 & & \\
Prob(F-statistic) & & 0,000000 & & \\
\hline
\end{tabular}


Berdasarkan Tabel 5 dapat dirumuskan persamaan regresi sebagai berikut:

$\mathrm{TA}=0,277+0,407 \mathrm{DAR}-0,804 \mathrm{ROE}-0,597 \mathrm{DAR}^{*} \mathrm{CG}+1,012 \mathrm{ROE}^{*} \mathrm{CG}$

Dari Tabel 5 tersebut terlihat bahwa Utang (DAR) tidak berpengaruh terhadap penghindaran pajak yang ditunjukkan dengan nilai koefisien sebesar 0,407 dan probabilitas sebesar 0,1317. Dengan demikian dapat disimpulkan bahwa Hipotesis 1 tidak terdukung. Variabel Profitabilitas (ROE) menunjukkan nilai koefisien sebesar -0,804 dengan probabilitas sebesar 0,0337. Dengan demikian dapat disimpulkan bahwa Hipotesis 2 yang menyatakan bahwa Profitabilitas berpengaruh negatif terhadap Penghindaran Pajak terdukung. Pada interaksi Utang x Tata kelola perusahaan (DAR *GCG) menunjukkan nilai koefisien sebesar -0,597 dengan probabilitas sebesar 0,3578. Sedangkan interaksi antara Profitabilitas x Tata kelola perusahaan $\left(\mathrm{ROE}^{*} \mathrm{CG}\right)$ menunjukkan nilai koefisien sebesar 1,012 dengan probabilitas 0,2486. Hasil tersebut menunjukkan bahwa Tata kelola perusahaan yang diukur dengan independensi komisaris tidak signifikan dalam menurunkan kecenderungan penghindaran pajak. Dengan demikian Hipotesis 3 dan 4 dalam penelitian ini tidak terdukung.

Berdasarkan hasil pengujian diatas, penelitian ini menunjukkan bahwa Utang tidak berpengaruh terhadap Penghindaran pajak. Secara teoretis, tingkat utang yang tinggi akan meningkatkan beban bunga yang selanjutnya diharapkan akan menurunkan beban pajak. Tapi di sisi lain, naiknya jumlah utang juga mengakibatkan semakin banyak pihak eksternal yang terlibat dalam perusahaan yang akan meningkatkan fungsi pengawasan terhadap manajemen perusahaan. Tingginya tingkat pengawasan akan meminimalisir tindakan penghindaran pajak yang akan dilakukan oleh perusahaan. Hasil penelitian ini tidak mendukung argumen hipotesis yang diajukan. Demikian juga, tidak mendukung hasil penelitian yang dilakukan oleh Mahdiana dan Amin (2020) dan Sunarsih dkk. (2019) yang menunjukkan bahwa utang berpengaruh positif terhadap penghindaran pajak maupun Dharma dan Ardiana (2016), Aprianto dan Dwimulyani (2019), dan Septiani dan Muid (2019) yang menunjukkan bahwa Utang berpengaruh negatif terhadap penghindaran pajak.

Hasil pengujian menunjukkan bahwa Hipotesis 2 terdukung yang berarti profitabilitas berpengaruh positif terhadap penghindaran pajak. Profitabilitas merupakan salah satu indikator yang mencerminkan performa perusahaan. Semakin tinggi nilai profitabilitas, maka akan semakin baik performa perusahaan. Tingginya tingkat laba yang diperoleh perusahaan menghasilkan jumlah pajak penghasilan yang akan meningkat pula seiring dengan meningkatnya laba perusahaan. Perusahaan dengan tingkat profitabilitas yang tinggi memiliki tagihan beban pajak penghasilan yang lebih besar dibandingkan dengan perusahaan yang memiliki tingkat profitabilitas rendah. Dengan demikian, perusahaan dengan tingkat profitabilitas yang tinggi akan cenderung melakukan praktik penghindaran pajak. Perusahaan akan berusaha untuk memanfaatkan celah dalam peraturan perpajakan guna meminimalisir pembayaran beban pajaknya. Hasil penelitian ini mendukung penelitian yang dilakukan oleh Dewinta dan Setiawan (2016), Praditasari dan Setiawan (2017), Pitaloka dan Merkusiwati (2019), dan Mahdiana dan Amin (2020) yang menunjukkan bahwa profitabilitas berpengaruh positif terhadap penghindaran pajak.

Variabel Tata kelola perusahaan dalam penelitian ini tidak memoderasi pengaruh Utang maupun Profitabilitas terhadap Penghindaran Pajak. Data satatistik deskriptif menunjukkan nilai median CG 33\% dan nilai rata-rata 35\%. Data ini menggambarkan bahwa komposisi komisari independent tidak cukup bervariasi. Angka ini memenuhi Peraturan Otoritas Jasa Keuangan Nomor 33/POJK.04/2014 tentang Direksi dan Dewan Komisaris Emiten Atau Perusahaan Publik ("POJK 33/2014"), yang mensyaratkan jumlah Komisaris Independen wajib minimal 30\% dari jumlah seluruh anggota Dewan Komisaris untuk perusahaan yang jumlah komisarisnya lebih dari 2 orang. Implisit bahwa perusahaan hanya sekedar memenuhi kewajiban perundangan-undangan. Hal ini terbukti dengan tidak efektifnya fungsi pengawasan komisaris independent dalam menurunkan praktik penghindaran pajak. 


\section{KETERBATASAN PENELITIAN}

Data awal yang tidak digunakan dalam penelitian ini relative besar sehingga memengaruhi jumlah sampel. Bayaknya sampel awal yang tidak memenuhi kriteria karena pada tahun 2019 dan 2020 kondisi perekonomian dunia sedang terpuruk. Selain itu, penelitian ini hanya menggunakan rasio dewan komisaris independent sebagai proksi Tata kelola perusahaan. Data deskriptif statistic menunjukkan bahwa rasio untuk variabel tersebut tidak cukup bervariasi karena perusahaa boleh jadi hanya sekedar memenuhi syarat rasio yang ditetapkan dalam peraturan perundang-undangan. Hal ini dapat berdampak pada tidak signifikannya variabel tersebut dalam memoderasi variabel independent yaitu Utang dan Profitabilitas.

\section{KESIMPULAN}

Penelitian ini bertujuan untuk menguji pengaruh Utang dan profitabilitas terhadap Penghindaran pajak yang dimoderasi dengan Tata kelola perusahaan. Hasil pengujian menunjukkan bahwa Utang tidak berpengaruh terhadap Penghindaran Pajak, sedangkan Profitabilitas berpengaruh negatif. Tata kelola perusahaan yang diprosi dengan rasio komisaris independen juga tidak memoderasi pengaruh kedua variabel independent terhadap variabel dependen. Hasil penelitian ini memberi menjadi gambaran bahwa rasio komisaris independen di perusahaan tidak cukup efektif dalam memitigasi praktik penghindaran pajak. Hal ini dapat menjadi masukan bagi regulator untuk mempertimbangkan kembali rasio komisaris independen di perusahaan yang disyaratkan sebesar minimal 30\%. Penelitian selanjutnya dapat menggunakan pengukur Tata kelola perusahaan yang lebih baik untuk memotret keefektifan peran Tata Kelola dalam menurunkan konflik keagenan.

\section{DAFTAR PUSTAKA}

Aprianto, M., \& Dwimulyani, S. (2019). Pengaruh Sales Growth dan Leverage terhadap Tax Avoidance dengan Kepemilikan Institusional sebagai Variabel Moderasi. Prosiding Seminar Nasional Pakar 2019 buku II. Diakses dari https://trijurnal.lemlit.trisakti.ac.id/pakar/article/view/4246

Arinda, H., \& Dwimulyani, S. (2019). Analisis Pengaruh Kinerja Keuangan dan Kualitas Audit Terhadap Tax Avoidance dengan Good Corporate Governance sebagai Variabel Moderasi. Jurnal Akuntansi Trisakti, 5(1), 123-140. http://dx.doi.org/10.25105/jat.v5i1.5246

Astari, N.P.N., Mendra, N.P.Y., \& Adiyadnya, M.S.P. (2019). Pengaruh Pertumbuhan Penjualan, Profitabilitas, Leverage, dan Ukuran Perusahaan terhadap Tax Avoidance. Kumpulan Hasil Riset Mahasiswa Akuntansi, 1(1), 166-182. Diakses dari https://ejournal.unmas.ac.id/index.php/kharisma/article/view/528

Boediono, G.S.B. (2005). Kualitas Laba: Studi Pengaruh Mekanisme Corporate Governance dan Dampak Manajemen Laba dengan Menggunakan Analisis Jalur. Simposium Nasional $\begin{array}{lllll}\text { Akuntansi } & \text { (SNA) Volo. DII } & \text { Diakses }\end{array}$ https://smartaccounting.files.wordpress.com/2011/03/kakpm-09 2.pdf

Darmawan, I., \& Sukartha, I. (2014). Pengaruh Penerapan Corporate Governance, Leverage, ROA, dan Ukuran Perusahaan pada Penghindaran Pajak. E-Jurnal Akuntansi, 9(1), 143-161. Diakses dari https://ojs.unud.ac.id/index.php/Akuntansi/article/view/8635

Desai, M. A., \& Dharmapala, D. (2006). Corporate tax avoidance and high-powered incentives. Journal of Financial Economics, 79(1), 145-179. https://doi.org/10.1016/j.jfineco.2005.02.002

Dewi, N., \& Noviari, N. (2017). Pengaruh Ukuran Perusahaan, Leverage, Profitabilitas dan Corporate Social Responsibility Terhadap Penghindaran Pajak (Tax Avoidance). E-Jurnal Akuntansi, 21(2), 882-911. Diakses dari https://ojs.unud.ac.id/index.php/Akuntansi/article/view/34029 
Dewinta, I.A.R., \& Setiawan, P.E. (2016). Pengaruh Ukuran Perusahaan, Umur Perusahaan, Profitabilitas, Leverage, dan Pertumbuhan Penjualan Terhadap Tax Avoidance. E-Jurnal Akuntansi, $\quad$ 14(3), 1584-1615. Retrieved from https://ojs.unud.ac.id/index.php/Akuntansi/article/view/16009

Dharma, I., \& Ardiana, P. (2016). Pengaruh Leverage, Intensitas Aset Tetap, Ukuran Perusahaan, dan Koneksi Politik Terhadap Tax Avoidance. E-Jurnal Akuntansi, 15(1), 584-613. Diakses dari https://ojs.unud.ac.id/index.php/Akuntansi/article/view/17463

Diantari, P., \& Ulupui, I. (2016). Pengaruh Komite Audit, Proporsi Komisaris Independen, dan Proporsi Kepemilikan Institusional Terhadap Tax Avoidance. E-Jurnal Akuntansi, 16(1), 702732. Diakses dari https://ojs.unud.ac.id/index.php/Akuntansi/article/view/20664

Fahmi, M., \& Prayoga, M. D. (2018). Pengaruh Manajemen Laba terhadap Nilai Perusahaan dengan Tax Avoidance sebagai Variabel Mediating. Liabilities (Jurnal Pendidikan Akuntansi), 1(3), 225-238. https://doi.org/10.30596/liabilities.vli3.2496

Haruman, T. (2008). Pengaruh Struktur Kepemilikan terhadap Keputusan Keuangan dan Nilai Perusahaan: Survey pada Perusahaan Manufaktur di Bursa Efek Indonesia. Simposium Nasional Akuntansi XI. 23-24 Juli 2008, Pontianak.

Hutagaol, J. (2007). Perpajakan Isu - Isu Kontemporer. Jakarta: Graha Ilmu.

Jensen, M. C., \& Meckling, W. H. (1976). Theory of the firm: Managerial behavior, agency costs and ownership structure. Journal of Financial Economics, 3(4), 305-360. https://doi.org/10.1016/0304-405x(76)90026-x

Mahdiana, M., \& Amin, M. (2020). Pengaruh Profitabilitas, Leverage, Ukuran Perusahaan, dan Sales Growth terhadap Tax Avoidance. Jurnal Akuntansi Trisakti, 7(1), 127-138. http://dx.doi.org/10.25105/jat.v7i1.6289

Muliawati, I. A., \& Karyada, I. F. (2020). Pengaruh Leverage dan Capital Intensity terhadap Agresivitas Pajak dengan Komisaris Independen sebagai Variabel Pemoderasi. Hita Akuntansi Dan Keuangan, 1(1), 495-524. Diakses dari https://ejournal.unhi.ac.id/index.php/HAK/article/view/788

Pitaloka, S., \& Merkusiawati, N. K. L. A. (2019). Pengaruh Profitabilitas, Leverage, Komite Audit, dan Karakter Eksekutif Terhadap Tax Avoidance. E-Jurnal Akuntansi, 27(2), 1202-1230. https://doi.org/10.24843/eja.2019.v27.i02.p14

Praditasari, A., \& Setiawan, P. (2017). Pengaruh Good Corporate Governance, Ukuran Perusahaan, Leverage dan Profitabilitas pada Tax Avoidance. E-Jurnal Akuntansi, 19(2), 12291258. Diakses dari https://ojs.unud.ac.id/index.php/Akuntansi/article/view/27647

Reinaldo, R. (2017). Pengaruh Leverage, Ukuran Perusahaan, ROA, Kepemilikan Institusional, Kompensasi Kerugian Fiskal, dan CSR terhadap Tax Avoidance pada Perusahaan Manufaktur Subsektor Makanan dan Minuman Terdaftar di BEI 2013-2015. Jurnal Online Mahasiswa Fakultas Ekonomi Universitas Riau 4(1), 45-59. Diakses dari https://jom.unri.ac.id/index.php/JOMFEKON/article/view/12182

Septiani, A., \& Mu'id, D. (2019). Pengaruh Corporate Social Responsibility, Corporate Governance, Leverage, dan Profitabilitas Terhadap Tax Avoidance. Diponegoro Journal of Accounting, $\quad 8(4), \quad 1-9 . \quad$ Retrieved $\quad$ from https://ejournal3.undip.ac.id/index.php/accounting/article/view/25831

Sinaga, C., \& Suardikha, I. (2019). Pengaruh Leverage dan Capital Intensity pada Tax Avoidance dengan Proporsi Komisaris Independen sebagai Variabel Pemoderasi. E-Jurnal Akuntansi, 27(1), 1-32. https://doi.org/10.24843/EJA.2019.v27.i01.p01

Sunarsih, S., Haryono, S., \& Yahya, F. (2019). Pengaruh Profitabilitas, Leverage, Corporate Governance, dan Ukuran Perusahaan Terhadap Tax Avoidance (Studi Kasus pada Perusahaan yang Tercatat di Jakarta Islamic Index Tahun 2012-2016). INFERENSI: Jurnal Penelitian Sosial Keagamaan, 13(1), 127-148. https://doi.org/10.18326/infsl3.v13i1.127-148

Wati, E., \& Astuti, S. (2020). Pengaruh Profitabilitas, Good Corporate Governance dan Intensitas Modal Terhadap Penghindaran Pajak pada Perusahaan Pertambangan Sektor Batu Bara di Bursa Efek Indonesia Periode 2016-2018. Jurnal Ilmiah Mahasiswa Manajemen, Bisnis Dan Akuntansi (JIMMBA), 2(4), 641-654. https://doi.org/10.32639/jimmba.v2i4.619 